\title{
BEBERAPA IMPLIKASI PERKEMBANGAN KOTA PADA RURAL URBAN FRINGE
}

\author{
Oleh: M. Musiyam
}

\begin{abstract}
$\overline{\text { ABSTRACT }}$
The percentage rate of Indonesia population that live in the urbans had rapidly increased since 1920 to 1990 . In the year 1920 the percentage reached 5.8 percent, in 1990 it had become 30.91 percent, while it is estimated that in the year of 2000 will seize at 38.3 percent.

The main implication of the above problem is that so much the raising demand of spatial to sustain the new functions in the urban. In respect thereof, the extension of towns function reaching the margin of the city will be no doubt.

So much the intensity of urban enlargement reaching the margin of the town; it will cause various problem. Firstly, the appearing of "under bounded city" phenomenon that often causes the "goal conflict" or spatial planning between the function areas. Secondly, in Java, the extending urbans which are getting increase should threaten the success in self-sufficient on rice, because for greater part of potential farmlands and rice supply in Indonesia are produced in $P$. Jawa. Considering to the agriculture sector and the development of urban, then, it is suggested two different strategy to develop the cities in $P$. Jawa and the other islands. It is suggested that urband development in Jawa to emphasize on farming orientation strategy with the protection to the potential farmland of towns margin; while to develop the cities in the other island apply the urban orientation strategy emphasizing town function development.
\end{abstract}

\section{$\overline{\text { INTISARI }}$}

Persentase penduduk Indonesia yang bertempat tinggal di perkotaan sejak tahun 1920 sampai 1990 telah meningkat dengan cukup pesat. Pada tahun 1920 persentase penduduk kota sebesar 5,8 persen, pada tahun 1990 meningkat menjadi 30.91 persen, dan perkiraan tahun 2000 menjadi 38,3 persen.

Implikasi utama dari persoalan diatas semakin meningkatnya permintaan akan ruang untuk menampung fungsi-fungsi baru di perkotaan. Sedang dipihak lain persediaan lahan dikota semakin terbatas. Oleh karena itu pemekaran fungsi-fungsi kota ke daerah pinggiran kota menjadi keniscayaan.

Semakin meningkatnya intensitas pemekaran kota ke daerah pinggiran kota menimbulkan beberapa persoalan. Pertama, munculnya fenomena "under bounded city" yang tak jarang memicu munculnya "goal conflict" dalam perencanaan tata ruang antar wilavah vang berdekatan. Kedua. untuk kota-kota di bulau Iawa. pemekaran 
kota yang semakin meningkat sedikit banyak akan mengancam prestasi swa sembada beras yang telah diraih, karena sebagian besar lahan potensial untuk pertanian dan suplai beras di Indonesia dihasilkan dari Pulau Jawa. Dengan mempertimbangkan sektor pertanian dan pengembangan kota maka disarankan dua strategi yang berbeda untuk pengembangan kota-kota di jawa dan luar jawa. Pengembangan kota-kota di jawa disarankan lebih menekankan strategi yang berorientasi pertanian dengan cara memproteksi lahan pertanian potensial di pinggiran kota. Sedangkan pengembangan kota-kota di luar jawa disarankan menerapkan strategi yang berorientasi kekotaan, dengan memberi prioritas pada pengembangan fungsi kota.

\section{PENDAHULUAN}

Fenomena perkotaan yang umum terjadi adalah bahwa cikal bakal masalah perubahan dan perkembangan kota disebabkan oleh dua hal. Pertama, karena faktor pertumbuhan penduduk kota; dan Kedua, karena perubahan dan pertumbuhan kegiatan masyarakat kota serta meningkatnya kebutuhan hidup mereka. Pada beberapa dekade terakhir kota-kota di negara-negara berkembang, termasuk kota-kota di Indonesia (terutama kota-kota besar) ditandai dengan pertumbuhan penduduk yang pesat dan diikuti meningkatnya tingkat urbanisasi (the level of srbanization). Pada tahun 1950, penduduk di negara-negara berkembang yang bertempat tinggal di perkotaan hanya $17 \%$, pada tahun 1970 bertambah menjadi $24,7 \%$, dan pada tahun 1990 meningkat lagi menjadi $37 \%$ atau kira-kira sebesar 1,5 milyar jiwa (Budhi Tjahyati dan Imron Bulkin, 1994).

Persentase penduduk Indonesia yang bertempat thingal di perkotaan sejak tahun 1920 sampai tahun 1990 telah meningkat dengan cukup pesat. Sensus tahun 1920 menunjukan bahwa hanya 5,8\% penduduk Indonesia yang bertempat tinggal di perkotaan, kemudian meningkat menjadi 17,03 \% pada tahun 1980 (Direktorat Jendral Cipta Karya,1985). Pada tahun 1990 tingkat urbanisasi di Indonesia meningkat menjadi 30,91\%, diperkirakan pada tahun 2000 menjadi $38,3 \%$ dan pada tahun 2005 meningkat lagi menjadi 57,22 \% (BPS, 1992).

Implikasi utama dari persoalan diatas adalah semakin meningkatnya permintaan akan ruang untuk menampung fungsi-fungsi baru di perkotaan yang semakin bertambah, dipihak lain persediaan lahan dikota semakin terbatas. Oleh karena itu maka pemekaran kota (urban sprazel), baik yang disengaja (intended urban sprawl) maupun yang alamiah menjadi keniscayaan.

Tulisan ini dimaksudkan untuk mengidentifikasi implikasi perkembangan kota (dalam arti horisontal) terhadap pinggiran kota (rural urban fringe). Untuk mengidentifikasi struk- 
tur daerah pinggiran kota digunakan pendekatan morfologi (morfological approach), sedangkan untuk menjelaskan proses perkembangannya digunakan pendekatan sistem (system approach).

\section{IDENTIFIKASI RURAL URBAN FRINGE}

Untuk mendapatkan kejelasan mengenai pengertian rural urban fringe, nampaknya perlu dijelaskan secukup nya mengenai pengertian urban, rural dan fringe. Kata Urban adalah kata sifat yang berkaitan dengan kehidupan kekotaan dan kata rural berkaitan dengan kehidupan kedesaan. Aspek kehidupan kekotaan maupun kedesaan dapat menyangkut aspek politik, sosial, ekonomi, budaya, psikologi, teknologi dan fisik (Hadi Sabari, 1994). Sedangkan kata fringe menunjukan pada pengertian garis batas antara "rural" dan "urban", walaupun dalam kenyataan merupakan suatu zone (Sinha, 1979). Dengan demikian maka secara umum pengertian rural urban fringe adalah suatu daerah pinggiran kota yang mempunyai ciri campuran antara sifat kehidupan kekotaan dan kedesaan. Dari pengertian di atas dapat dibedakan menjadi daerah yang ciriciri kekotaannya lebih dominan (urban fringe) dan daerah yang ciri-ciri kedesaannya lebih dominan (rural fringe).

Batasan pengertian rural urban fringe di atas masih terasa longgar sehingga sulit dioperasionalkan dalam penelitian. Rabyn J. Prior (1971) mengusulkan teknik analisis untuk mengidentifikasi daerah rural urban fringe melalui pendekatan morfologi dengan menggunakan presentase penggunaan lahan perkotaan, presentase penggunaan lahan pedesaan dan jarak dari lahan kekotaan terutama (built up land) ke lahan kedesaan utama sebagai diferensiatornya. Ketiga komponen ini digabungkan sedemikian rupa dalam segitiga penggunaan lahan desa-kota (rural urban land use triangle).

Penyusunan model dari Prior ini disadari oleh ide adanya transformasi gradual dari kota ke desa dan sebaliknya, dimana semakin jauh dari daerah kota makin kabur kenampakan kekotaannya dan makin jelas kenampakan kedesaannya. Atau dengan kata lain semakin mendekati daerah perkotaan dominasi bentuk-bentuk penggunaan lahan kekotaan makin besar dan begitu pula sebaliknya. Dalam memandang keberadaan kota sebagai regional city, berdasar penggunaan lahannya Prior membagi menjadi 4 Subzone, yaitu: (1) urban area, (2) urban fringe, (3) rural fringe dan (4) rural area.

Urban area adalah daerah yang bentuk penggunaan lahannya betulbetul berorientasi non pertanian, sedangkan rural area adalah daerah yang penggunaan lahannya sepenuhnya berorientasi pertanian. Subzone urban fringe adalah daerah yang terletak bersebelahan dan ada hubungan langsung de- 
ngan urban area dengan proporsi penggunaan lahan yang berorientasi kekotaan (komersial, industri, dan fungsi kekotaan lain), alih fungsi lahan dari ke non pertanian, dan lahan kosong yang tidak digunakan untuk pertanian lebih tinggi dengan rata-rata dari nural urban fringe. Sedangkan rural fringe adalah daerah yang bersebelahan dengan urban fringe dengan proporsi penggunaan lahan untuk perlanian dan konversi lahan dari pertanian ke non pertanian lebih dari rata-rata di rural urban fringe.

Perlu disadari bahwa pembagian zone-zone di atas merupakan model konseptual. Tidak semua kota selalu ditandai dengan alih aturan subzone seperti dalam model tersebut dan persebarannya tidak selalu merata ke segala arah. Karena hal ini berkaitan dengan variasi lingkungan fisikal pada masing-masing kota yang dapat berfungsi sebagai kendala maupun pemacu terhadap perembetan kenampakan kekotaannya. Keberadaan jalur ransportasi, titik-titik pertumbuhan, peraturan-peraturan zoning, spekulasi lahan adalah beberapa contoh unsurunsur yang menyebabkan terjadinya penyimpangan model ideal tersebut di lapangan.

Salah satu teori menjelaskan fenomena dan proses perubahan pengsunaan lahan di kota adalah teori "kekuatan sentripetal dan sentrifugal" dari charles Colby (dalam Hadi Sabari, 1994). Ide dasar,teori ini adalah bahwa didalam kota terdapat kekuatan dinamis yang mempengaruhi pola penggunaan lahan kota, sehingga sifatnya tidak statis. Faktor-faktor penambahan dan pengurangan bangunan, perubahan fungsi bangunan penambahan dan pengurangan fungsi-fungsi perkotaan, perubahan nilainilai kehidupan dalam berbagai aspek kehidupan dari waktu ke waktu telah menyebabkan kota menjadi bersifat dinamis, termasuk pola penggunaan lahannya.

Secara garis besar, kekuatan-kekuatan dinamis tersebut dapat dikelompokkan menjadi dua, yaitu: Pertama, kekuatan-kekuatan sentrifugal, dan Kedua, kekuatan-kekuatan sentripetal. Colby membagi daerah perkotaan menjadi tiga bagian, yaitu; (1) bagian sentral dari kota (2) Bagian tengah, dan (3) bagian paling luar atau pinggiran (lihat gambar 1). Masing-masing zone tersebut mempunyai karakteristik keruangan yang memungkinkan sebagai tempat asal perpindahan (place of origin) maupun tempat tujuan perpindahan (place of destination).

Kekuatan sentrifugal disini adalah kekuatan-kekuatan yang menyebabkan terjadinya pergerakan penduduk dan fungsi-fungsi perkotaan dari bagian dalam suatu kota menuju bagian luarnya. Tidak semua gerakan sentrifugal berasal dari bagian dalam suatu kota, tetapi dapat berasal pula dari bagian paling dalam menuju kebagian tengah, atau berasal dari bagian tengah 


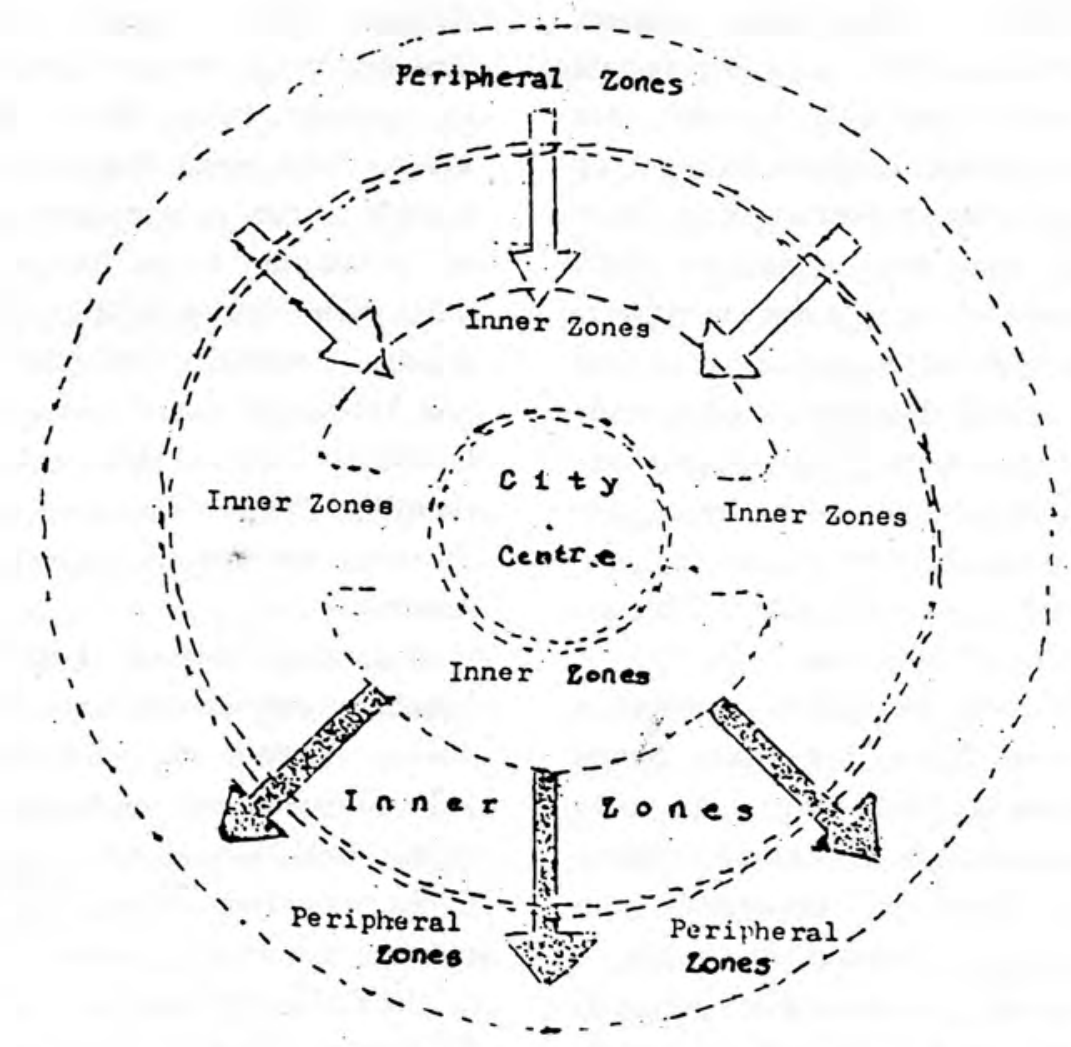

\begin{tabular}{|c|c|c|}
\hline & $\begin{array}{c}\text { PULL FORCES } \\
\text { (place of destination) }\end{array}$ & $\begin{array}{l}\text { PUSH FORCES } \\
\text { (Place of origin) }\end{array}$ \\
\hline $\begin{array}{l}\text { CENTRIPETAL } \\
\text { MOVEMENT }\end{array}$ & $\begin{array}{l}\text { ATTRACTIVE QUALITIES OF } \\
\text { INNER ZONES : } \\
- \text { high access to rest of city } \\
- \text { high access to other central firms } \\
\therefore \text { prestige sites } \\
- \text { many services \& facilities, etc } \\
\end{array}$ & $\begin{array}{l}\text { UNATTRACTIVE QUALITIES OF } \\
\text { PERIPHERAL ZONES : } \\
- \text { low acces to rest of city } \\
- \text { lack of many services } \\
- \text { lack of many facilities } \\
- \text { low prestige sites. ctc }\end{array}$ \\
\hline $\begin{array}{l}\text { CENTRIFUGAL } \\
\text { MOVEMENT }\end{array}$ & $\begin{array}{l}\text { ATTRACTIVE QUALITIES OF } \\
\text { PERIPHERAL ZONES : } \\
- \text { pleasant environment } \\
- \text { plenty cheap land } \\
- \text { access to axial and circumferen- } \\
\text { tial transport } \\
- \text { less traffic congestion } \\
- \text { frec from pollution. etc }\end{array}$ & $\begin{array}{l}\text { UNATTRACTIVE QUALITIES OF } \\
\text { INNER ZONES : } \\
- \text { congestion } \\
- \text { cxpensive land } \\
- \text { land shortage } \\
\therefore \text { prohibitive regulations } \\
- \text { high taxes } \\
- \text { pollution. etc }\end{array}$ \\
\hline
\end{tabular}

Gambar 1. Kekuatan-kekuatan Dinamis yang Mempengaruhi Struktur Keruangan Kota (Model Charles Colby) 
menuju ke bagian paling luar. Sedangkan kekuatan sentripetal adalah kekuatan-kekuatan yang menyebabkan terjadinya pergerakan baik penduduk maupun fungsi-fungsi yang berasal dari bagian luar menuju ke bagian dalam perkotaan. Seperti pada pergerakan sentrifugal tidak semua gerakan berasal dari bagian luar kota menuju ke bagian paling sentral, tetapi dapat berasal dari bagian luar menuju ke bagian tengah atau berasal dari bagian tengah menuju ke bagian paling sentral. Terjadinya kekuatan-kekuatan sentrifugal dan sentripetal karena adlanya faktor pendorong dan faktor penarik. Semakin kuat faktor-faktor ersebut akan semakin besar kekuatan sersebut dan sebaliknya. Demikian pula bekuatan pergerakan (movement) pensoduk dan fungsi-fungsi dari bagian clam ke bagian luar dan sebaliknya.

Bagaimana kaitan teori tersebut Sengan dinamika perubahan di daerah ginggiran kota? Berbagai persoalan seperti: meningkatnya jumlah pendaduk dan kebutuhan hidup masyanlat perkotaan, ruwetnya transportasi, polusi, tidak terjamin privacy, tingginya karga lahan, dan semakin meningkatsya fungsi kota, telah menyebabkan perpindahan penduduk dan fungsifengi perkotaan ke daerah pinggiran kisa

Penduduk kelas menengah di kota beervak yang pindah ke pinggiran kota karena alasan harga lahan yang relatif sendah di pinggiran kota, sehingga memungkinkan membangun rumah yang lebih besar dengan privacy yang lebih terjamin. Bagi mereka jarak yang relatif jauh dari kota tidak menjadi persoalan yang penting, karena sebagian besar dari mereka mempunyai sarana trasportasi yang memadai dan disamping itu juga ditunjang prasarana transportasi kota-pinggiran kota yang semakin baik. Akibat lanjut dari proses ini adalah munculnya gejala filtering up, yakni pergantian pemukimpemukim di daerah pinggiran-pinggiran kota dari pemukiman-pemukiman yang lebih rendah tingkat ekonominya ke pemukim-pemukim yang lebih tinggi tingkat ekonominya. Disamping hal diatas proses perpindahan penduduk dari kota ke pinggiran kota juga disebabkan oleh semakin besarnya peran developer dalam penyediaan rumah. Para developer cenderung membangun komplek-komplek perumahan di daerah pinggiran kota karena pertimbangan ketersediaan lahan dan rendahnya nilai lahan (land value) di daerah pinggiran kota, sehingga keuntungan yang diperoleh semakin besar. Gejala-gejala di atas dapat dengan mudah diamati pada kota-kota di Jawa. Sebagai contoh misalnya tumbuhnya perumahan-perumahan kelas menengah dan menengah ke atas serta komplek pemukiman di sekitar kota Yogyakarta dan Surakarta.

Dengan semakin sempitnya lahan yang tersedia di perkotaan dan harga lahan yang semakin tinggi, disisi lain 
pembangunan industri modern di perkotaan semakin meningkat menyebabkan ekspansi industri memilih di daerah pinggiran kota karena pertimbangan ketersediaan lahan dan relatif rendahnya harga lahan di pinggiran kota. Dengan semakin berkembangnya industri di pinggiran kota berarti kesempatan kerja di pinggiran kota pada sektor industri semakin meningkat pula. Hal ini akan menjadi daya tarik bagi para pencari kerja, terutama dari daerah pedesaan.

Hadirnya fungsi-fungsi sebagai mana disebut di atas akan memacu tumbuhnya kegiatan-kegiatan lain seperti perdagangan dan jasa di pinggiran kota (multiplier effect). Dengan demikian dari waktu ke waktu daerah pinggiran kota akan berkembang ke arah yang lebih menampakkan sifat-sifat kekotaan, baik dalam hal tata fisikalnya, tata sosial ekonomi dan orientasi budayanya.

\section{BEBERAPA IMPLIKASI}

Perembetan sifat-sifat kekotaan ke daerah pinggiran kota memunculkan beberapa implikasi yang tidak jarang perlu pemecahan. Implikasi-implikasi tersebut dapat berkait dengan aspek kebijakan, ekonomi, sosial dan tata fisikalnya. Sebagai akibat perembetan sifat-sifat kekotaan ke daerah pinggiran kota, dari waktu ke waktu bentuk fisik kota selalu mengalami perluasan, sementara itu batas administrasi kota relatif sama untuk periode waktu yang lama. Penentuan batas administrasi kota dimaksudkan untuk memberikan batas terhadap permasalahan-permasalahan kota se hingga memudahkan pemecahan-pemecahan persoalan politik, sosial, ekonomi, budaya dan fisik yang ditimbulkannya. Oleh karena batas fisikal kota selalu bertambah setiap saat, maka sering sekali terjadi bahwa batas fisikal kota berada jauh di luar batas administrasi kota. Kondisi kota yang demikian disebut under bounded city. Kenampakan demikian dapat ditemukan dengan mudah pada kota-kota di Jawa. Sebagai contoh untuk kota Surakarta, daerah pabelan yang secara morfologis merupakan kelanjutan dari perkembangan kota Surakarta, tetapi secara administratif masuk Kabupaten Sukoharjo. Demikian pula untuk Yogyakarta, Daerah Condongcatur secara morfologis merupakan ke lanjutan dari perkembangan kota Yogyakarta tetapi masuk dalam administrasi Kabupaten Sleman.

Pada kondisi under bounded city, sering muncul beberapa persoalan, diantaranya dalam hal pengaturan wilayah. Wewenang pemerintah kota untuk merencanakan tata ruang wilayah hanya terbatas pada daerah yang termasuk dalam batas administrasi kota bersangkutan, sementara daerah perkotaan yang terletak di luar batas administrasi kota menjadi wewenang pemerintah daerah yang lain. Karena pemerintah kota dan pemerintah 
daerah yang biasanya mempunyai penekanan prioritas pengembangan yang berbeda, maka dimungkinkan akan terjadi konflik tujuan (goal casflict) dalam perencanaan tata ruang. Kalau hal ini terjadi maka akan muncul dampak negatif terhadap pengembangan wilayah di daerah bersangkutan, khususnya dalam hal pengadaan fasilitas-fasilitas umum.

Salah satu pemecahan logis dari persoalan di atas adalah memperluas batas administrasi kota. Namun dalam pelaksanaanya tidak semudah dalam seori karena pemerintah daerah akan membuat banyak pertimbangan untuk melepaskan sebagian daerahnya tersebut. Bagi pemerintah daerah pelepasan sebagian daerahnya akan menimbulkan beberapa konsekuensi negatif seperti konsekuensi keuangan dan konsekuensi prestise. Pada wilayah dimana terdapat fungsi-fungsi yang menjadi sumber pendapatan daerah jelas akan memberatkan pemerintah untuk melepaskannya. Kegagalan upaya untuk memperluas batas administrasi kota Yogyakarta adalah contoh betapa sulitnya pelaksanaan perluasan kota. Pemerintah daerah Sleman merasa berkeberatan melepaskan wilayahnya yang berada di batas jalan lingkar Yogyakarta karena karena sepertiga pendapatan aslinya dihasilkan dari wilayah tersebut. Di samping iou wilayah bersangkutan terdapat fungsifungsi yang prestisius seperti Universitas Gajah Mada, IKIP Negeri,
Rumah Sakit Sardjito dan beberapa fungsi lainnya.

Implikasi lain dari adanya under bounded city adalah timbulnya kesulitan dalam melakukan analisis urbanisasi. Ini karena data statistik yang terliput tidak sepenuhnya mencerminkan keadaan kota yang bersangkutan. Arealareal kekotaan yang telah jauh di luar batas administrasi kota tidak terliput pada data pemerintah kota tetapi terliput pada pemerintah daerah bersangkutan yang pencatatannya mendasarkan pada unit administrasi yang ada. Pesatnya pemekaran kota, terutama untuk kota-kota di Jawa mengandung dilema antara kepentingan perkotaan dengan kepentingan mempertahankan swa-sembada (self suficiency) beras di Indonesia. Untuk Indonesia salah satunya mengandalkan sektor pertanian sebagai tulang punggung perekonomian nasional, dampak dari pemekaran kota menyebabkan pesatnya alih fungsi lahan pertanian yang subur dan beririgasi baik ke fungsi lahan non pertanian menjadi persoalan yang berat. Sehingga apabila proses demikian dibiarkan maka prestasi swasembada beras yang telah dicapai akan terancam. Karena alasan itulah beberapa waktu yang lalu Presiden melalui Menteri Negara Agraria/ Kepala Badan Pertanahan Nasional menginstruksikan untuk melarang pendirian perumahan di wilayah pertanian yang beririgasi teknis maupun wilayah pertanian yang ber- 
potensi menjadi sawah beririgasi teknis.

\section{$\overline{\text { PENUTUP }}$}

Dengan mempertimbangkan kepentingan sektor pertanian sekaligus kepentingan perkembangan kota, Hadi Sabari (1990) menyarankan dua strategi yang berbeda untuk mengembangkan kota-kota di Jawa dan kota-kota di luar Jawa. Kondisi di Jawa dibanding dengan luar Jawa ditandai dengan : (1) Kesuburan tanah yang lebih baik, (2) Jaringan irigasi lebih baik, (3) Lahan pertanian sulit diperluas, (4) Produksi pertanian lebih instensif, (5) Pemilikan lahan relatif sempit, (6) Tekanan kota terhadap lahan pinggiran kota lebih besar, dan
(7) Pola pemekaran kota lebih didominasi pola leap frog dan ribban.

Atas pertimbangan-pertimbangan di atas untuk kota-kota di Jawa disarankan menerapkan strategi yang berorientasi pertanian (rural oriented strategy), dengan cara memproteksi lahan pertanian potensial di pinggiran kota. Sedangkan untuk kota-kota di luar Jawa disarankan menerapkan strategi yang berotientasi kekotaan (urban oriented strategy). Ini dimungkinkan karena tekanan perkotaan terhadap daerah pinggiran kota relatif masih kecil disamping kesuburan tanahnya relatif rendah dengan jaringan irigasi relatif kurang baik dan ekstesifikasi pertanian masih sangat dimungkinkan. 


\section{DAFTAR PUSTAKA}

Biro Pusat Statistik, 1992, Penduduk Indonesia Hasil Sensus Penduduk 1990, BPS, Jakarta.

Ditjen Cipta Karya, Dep. Pekerjaan Umum, 1985,Final Report, National Urban Developments Strategies, Jakarta.

Prior, Robin J., 1971, Defining of rural urban fringe, in larry S. Bourne (ed), Internal Structure of the city: Readings on space and Environment, Oxford University Press, New York.

Sinha, MMP, 1979, Impact of Urbanization on land Use in The Rural. Urban Fringe, Concept Publishing Company, New Delhi.

Tjahyati S, Budhy dan Imron Bulkin, 1994, Arahan Kebijaksanaan Tata Ruang. Nasional: Studi Kasus Jabotabek, Prisma: XXIII (2), Februari 1994, LP3ES, Jakarta.

Yunus, Hadi Sabari, 1990, Searching New Strategies For Managing and Controlling Urban Land Growth : A Preliminary out look on Indonesia, Indonesia Journal of Geography, 60 (20) December 1990, Faculty of Gegography Gadjah Mada Universiy, Yogyakarta.

1994, Teori dan Model Struktur Keruangan Kota, Fak. Geografi UGM, Yogyakarta. 